\title{
A study on the effect of the innovation management on entrepreneurial activities in Iran and the state-members of GEM
}

\author{
Zahra Arab $^{a^{*}}$, Sakineh Noori Nasab ${ }^{b}$, Rahmatollah Azad ${ }^{c}$ and Fariba Zolfagharee ${ }^{d}$
}

\begin{abstract}
${ }^{a}$ Master student of Industrial Management, Islamic Azad University, Semnan Branch, Semnan, Iran
${ }^{b}$ Master in Industrial Management, Instructor of Islamic Azad University, Shahmirzad Branch, Iran

${ }^{c}$ Department of industrial management, Islamic Azad University, Bobol branch, Iran

${ }^{d}$ Master Student of Educational Administration, Payam Noor University, Shahrerey Branch, Iran

\section{A R T I C LE I N F O}

\section{Article history:}

Received March 29, 2012

Received in Revised form

June, 12, 2012

Accepted 19 June 2012

Available online

June 272012

Keywords:

Entrepreneurial Comprehensions

(concepts)

Innovation Management

Structural Equations Modeling

\begin{abstract}
A B S T R A C T
The rapid technological changes in recent decades have created tremendous motivations among entrepreneurs to offer value added products and services. The complicated relationships between technology and innovation have caused to create the innovation management. Therefore, the key prominence of innovation in global village is to design new plans to manage and improve the innovation so that they could continue aiming at their superior nationalorganizational goals along with their growth and improvement path within their strategic plans. Many countries are interested in comparing themselves with other societies for enhancing their entrepreneurial awareness in an approximate rate and exploit their successful and positively affecting on development of the entrepreneurship innovation-management experiences and policies. In this research, the impact of each determinant of innovation management influencing on entrepreneurial activities in Iran and the members of Global Entrepreneurship Monitor between 2008 and 2011 is studied and evaluated using the structural equations.
\end{abstract}

C 2012 Growing Science Ltd. All rights reserved.

\section{Introduction}

The importance of entrepreneurship for economic growth is stressed by Schumpeter, who defines "innovation" as a new combination, with five types of activities such as new product development and adaption of new process (Kazuyuki, 2011). Entrepreneurship is the continuing generation of innovation in response to perceived opportunities in the business environment. In start-up of business, the entrepreneur is regarded as the key factor in developing a business idea, marshalling resources, and creating an enterprise to bring a new product or service to the market. In a competitive business environment, the entrepreneur and the enterprise should continue to look for now opportunities and make the necessary arrangement to convert them into new goods and services. Innovation should, 
therefore, impregnate the entire enterprise for the creation and invention of competitive edge and relevancy in the market place.

Drucker (1985) argued that innovation is the tool of entrepreneurship. In addition, both innovation and entrepreneurship demand creativity and creativity is moving from the known to the unknown. No entrepreneur or enterprise can continue to hold a place of leadership unless it recognizes that modern business operates in a world of galloping change, which creates new problems, risk and opportunities and for which they have to mobilize the enterprise's resources before changes make their impact felt.

Innovation is defined as adding something new to an existing product or process. All innovation begins with creative ideas and creativity is the starting point for innovation. Creativity is however necessary but not sufficient condition for innovation. Innovation is the implantation of creative inspiration. Innovation is the successful development of competitive advantage and as such, it is the key to entrepreneurship. The entrepreneurs are the "dreamers", who take hands on responsibility for creating innovation. It is the presence of innovation, which distinguishes the entrepreneur from others. Innovation, must therefore, increase competitiveness through efforts aimed at the rejuvenation, renewal, and redefinition of organizations, their markets or industries, if business are to be deemed entrepreneurial.

OECD (2001) identified entrepreneurship and innovation as two of the four microeconomic drivers of economic growth in the knowledge based economy. Hoffman (2005) identified entrepreneurship as one of the four drivers of innovation, 4 together with human resources, knowledge building and sharing, and internet and communication technology (ICT). Gabr and Hoffman (2006) explained that there are five drivers of entrepreneurship: opportunity, abilities, capital, incentives, and culture, each one influenced by a comprehensive list of policy instruments. From this, they have developed a general policy framework of the growth drivers of entrepreneurship, where they define more in terms of innovative (high growth) entrepreneurship rather than small business. In the view of Arundel and Hollanders (2005), entrepreneurship is possibly one of the most important drivers of innovation, yet one of the most difficult to measure because it involves attitudes to risk, opportunities that reduce risk, receptiveness to new ideas, and access to capital. Audretsch and Thurik (2001) and Acs et al. (2005) proposed that entrepreneurs are critical to the innovation process and that entrepreneurial capacity is a key element in the transfer of knowledge in the commercialization process.

In this study, we perform a survey on innovation by electing countries of Global Entrepreneurship Monitor as the main case study and collecting countries' updated information. The study uses necessary statistics in 6 scopes of innovation and management and 4 basic dimensions of mental property right. The methodology of this research for examination of introduced countries includes usage of structural equations system for distinguishing fundamental researching variable's relationships and determining the coefficient of their importance.

\section{Literature review}

\subsection{Innovation and its management}

Innovation is one of effective agents in survival and success of any knowledge oriented organisation. According to Kanter (1995) innovation process is the collection of every one's fresh \& fruitful ideas in resolving problems and totally consists of idea formation, admission and implementation of new ideas in processes, products and services (Shah Hoseini \& Kavoosi, 2009). In another description, innovation is admitting an idea or behaviour, which is fresh for market, industry and public atmosphere of organisation (daft, 2009). Halt (1998) used the expression of innovation in a wider concept and as a process for usage of knowledge or related information to introduce or produce new useful things. 
Innovation is every newly reviewed and renovated one, which is designed, realized and strengthens the organization's statue against the competitors and it provides a long-term competitive advantage. In other word, innovation is a realized creative thought, which led to improvement of processes \& products. Innovation is divided into 5 forms:

1-Introduction and commercializing of new products or services or fundamental improvement in function of current products and services,

2-Introduction of new production process or improvement in current working process,

3- Making new market,

4- Development of new supplying resources, such as raw materials, equipments and other inputs,

5-Forming fundamental modification within organisational and industrial structure (Sarir Afraz, 2010).

In fact, innovation management is a process through combination and integration of different knowledge components making the inventions. In this way, usage of implicit knowledge as a basic trigger in successful innovation process will have a considerable impact on efficiency of companies and can be defined as a variable that effecting single or several features. These changes can be occurred through different mechanism in management and if it encompasses one out of three underneath mentioned conditions, it can lead to create sustainable competitive advantage.

If innovation serves as a new basic platform and challenges managerial beliefs covering a range of process and approaches, it becomes as part of invention plan, which progresses during time horizon and achieves a combinational statue (Big et al., 2005). Today mentality of "work, only for himself" has vanished from the literature of innovation management and most of management followers must refresh their organizational strategies (Huizingh, 2011). In 2009 released Brem and Voigt innovative model, once an organization plans for its own technology, it might blends two strategies of "technology pulling \& market pushing", where such blending and synchronizing are considered as the basic innovation management (Cateno, 2011). The process of market pushing is based on the existence of invention of new technology that organization accepts it and tries to find a profitable demand to use that technology. The process of technology pulling tries to find where consumer's requisitions are ignored and tries to expand concentration to come up with some solution for (Boutellier, 2000; Trott, 2005).

\subsection{Entrepreneurial activities}

There are the ones associated with launching or managing a new business, which can be done by someone or with the help of others. The definition of the concept of opportunism in entrepreneurship science is totally different from that in literature. For example, Kerzener (1973) believed that opportunities are like paper money spreading over the sidewalk expecting a watchful person to pick them up. In contrast, Schumpeter (1942) claimed that opportunities need significant amount of investments to be exploited and commitment to their exploitation can only be found in the most organized minds. Casson and wadeson (2007) in Hike's research (1945) reflected the concept of opportunity is in localized knowledge of market factors in competitive prices, which is a symptom of relevant shortage, as well as how they change from one place to another. Casson (1982) believes that entrepreneurial opportunities are the ones used for making new goods, giving new services, providing raw materials, and designing new organizing ways, all of which make it possible for the output to be sold with a price higher than that of the production. According to Krouger (2006), opportunity is a condition for desirable and possible future decision makers. Venkatraraman (2002) defines opportunity as an idea or innovation, which would lead to financial gains and believes that their 
achievement depends on the appropriateness of conditions and activities, which make the results practical through financial artifacts. Timmons (1999) states "in fact, opportunities constitute a process which is like particles clash in an atomic reaction or the reproduction of the fish in an ocean after the hurricane." Ideas coincide in the world of reality and as a result of entrepreneurial innovation can lead to an opportunity. Timmons believes that an opportunity must be attractive and on time, and create added value for buyer or consumer (Dellabaraca, 2002).

\section{Theoretical framework of the study}

This study focuses on comparing entrepreneurship condition in Iran compared with GEM countries. In this regard, a conceptual model has been developed, which demonstrates the relationship between latent and observed variables. In this model, the relationship between the latent variables of innovation management and entrepreneurial activities has been investigated. In the case of the first variable (innovation Management ) Capacity for innovation, Quality of scientific research institutions, Company spending on $\mathrm{R} \& \mathrm{D}$, University-industry collaboration in $\mathrm{R} \& \mathrm{D}$, government procurement and advanced technology products, Availability of scientists and engineers. (i.e., entrepreneurial activities), observed variables are perceived opportunities, perceived capabilities, entrepreneurial intention, and fear of failure. Fig. 1 shows the proposed framework of our study and Table 1 presents research's hypotheses.

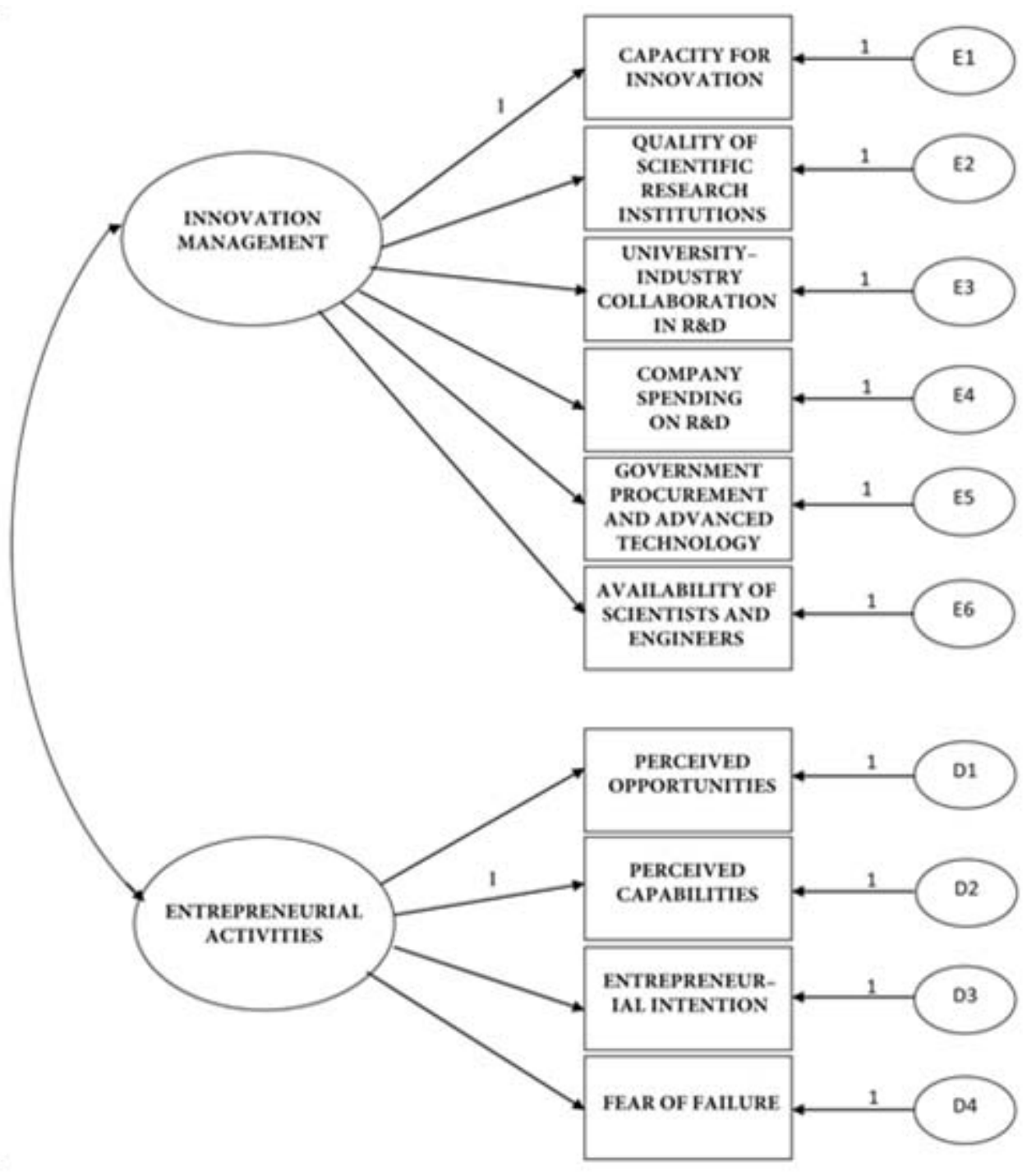

Fig. 1. Conceptual model 
Table 1

Research hypotheses

\begin{tabular}{ll}
\hline Hypotheses & Description of the hypotheses \\
\hline 1 & $\begin{array}{l}\text { There is a relationship between the latent variable of innovation Management and } \\
\text { its observed variables }\end{array}$ \\
2 & $\begin{array}{l}\text { There is a relationship between the latent variable of innovation Management and } \\
\text { observed variables of Entrepreneurial activities }\end{array}$ \\
There is a relationship between the latent variable of Entrepreneurial activities and \\
its observed variables \\
Entrepreneurial activities have an effect on innovation Management
\end{tabular}

\subsection{Methodology}

With respect to the aim, this study is classified as an applied research and, with the consideration of methodology, it is categorized as a co-relational one. The information obtained from global entrepreneurship monitor constituted the data for the study. In addition, structural equation modeling and AMOS software were used for data analysis. The sample included all the countries, which are the members of GEM; it included Iran and 22 OECD countries.

Innovation Management variables which have been introduced by WEF and have been recognized as international indices include: Capacity for innovation, Quality of scientific research institutions, Company spending on $\mathrm{R} \& \mathrm{D}$, University-industry collaboration in $\mathrm{R} \& \mathrm{D}$, government procurement and advanced technology products, Availability of scientists and engineers (WEF,2011) and entrepreneurial activities variables which have been introduced by GEM and have been recognized as international indices include: Perceived opportunities, Perceived capabilities, Entrepreneurial intention, Fear of failure rate (GEM,2009).

In this article Structural equation modeling was used to study the effect of independent variables of innovation Management and entrepreneurial perceptions between 2008 until 2011. Structural equation modeling is a comprehensive statistical method for testing hypotheses on possible relationships among observed and latent variables and is usually known as covariance structural equation modeling, causal modeling, and LISREL; however, the most famous term is structural equation modeling (SEM) (Human,2005). There are at least four reasons for its wide use: first, researchers have become more conscious about the need to use multiple observed variables for better understanding of their scientific, research based area; second, researchers are paying more attention to the importance of the validity and reliability of the scores obtained through measurement instruments; third, in the last thirty years, SEM has been able to analyze more advanced conceptual structural models; finally, SEM software pachake are increasingly becoming user friendly (Richard,2009).

Confirmatory factor model is plotted in Fig. 1 and included 8 Measurement equation in the model as follows,

Capacity for innovation $=$ function of innovation Management + e1

Quality of scientific research institutions = function of innovation Management $+\mathrm{e} 2$

Company spending on $R \& D$ = function of innovation Management + e3

University-industry collaboration in R\&D = function of innovation Management + e4

government procurement and advanced technology products = function of innovation Management + e5

Availability of scientists and engineers $=$ function of innovation Management + e6

Perceived opportunities $=$ function of entrepreneurial activities $+\mathrm{d} 1$

Perceived capabilities $=$ function of entrepreneurial activities $+\mathrm{d} 2$

Entrepreneurial intention $=$ function of entrepreneurial activities $+\mathrm{d} 3$

Fear of failure rate $=$ function of entrepreneurial activities $+\mathrm{d} 4$ 
Most experts suggest that to increase the accuracy of the study, it is better to used different criteria for evaluating the model, to have a better economic comparison.

\section{The structural equations}

Based on the interpretations and the statement of competitive advantages of the enhancement of entrepreneurial perceptions, one can conclude that more than any other time, the world's countries are in need of educations about innovation management as a factor, which enhances entrepreneurial activities. Structural equation modeling is in fact a model for drawing the relationship among variables. The primary objective is to provide a background for quantitative analysis of conceptual models. The present study has used data from GEM and WEF; countries' data on entrepreneurial activities and innovation management in 2008, 2009, 2010 and 2011 were collected. The basic hypothesis is that there is a relationship between entrepreneurial activities and innovation management. Table 2,3,4,5 demonstrates the average rate of entrepreneurial activity and innovation management of the GEM and WEF Member 's from 2008 until 2011.

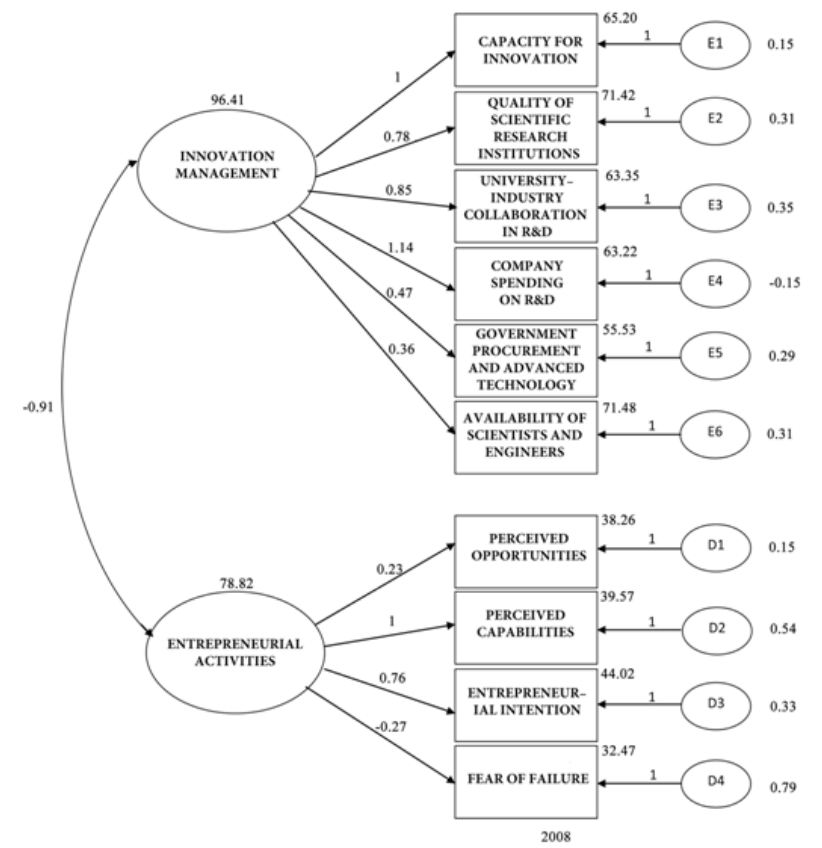

Fig. 2. structural equation modeling for The main variables in 2008

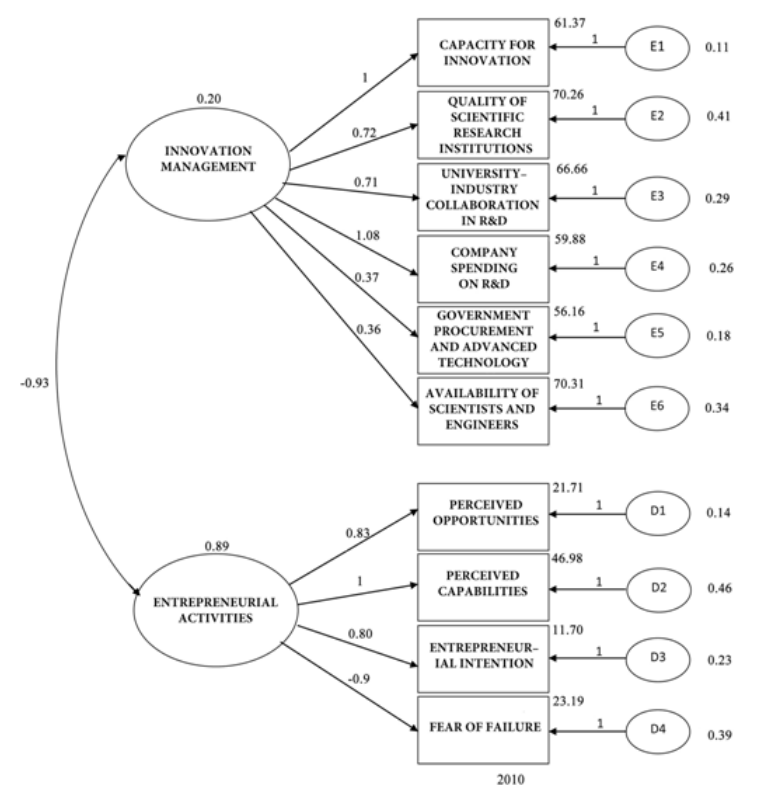

Fig. 4. structural equation modeling for The main variables in 2010

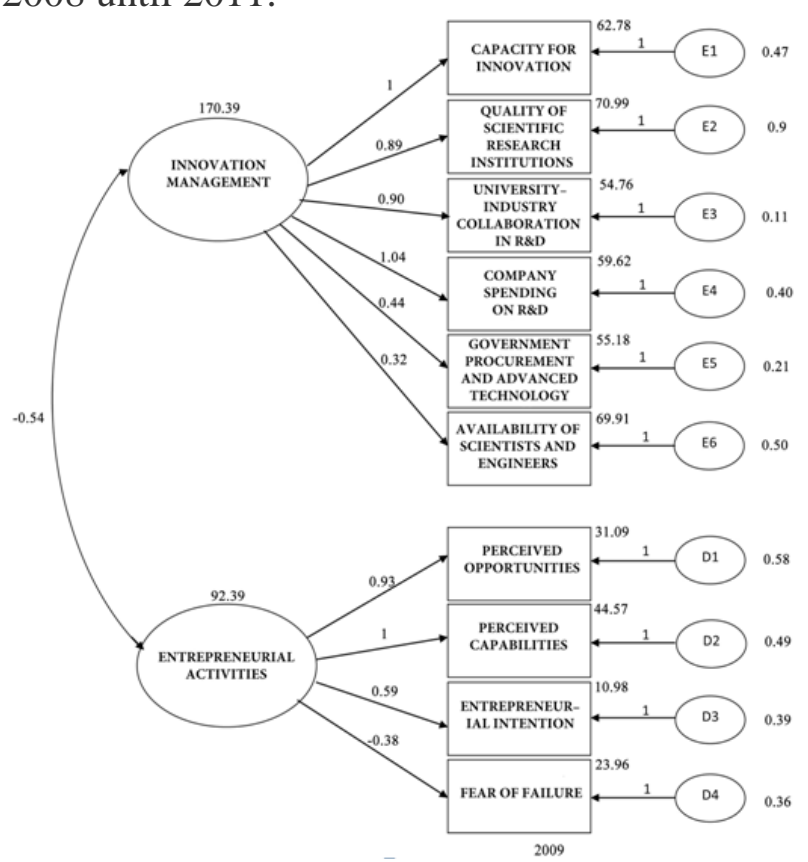

Fig. 3. structural equation modeling for The main variables in 2009

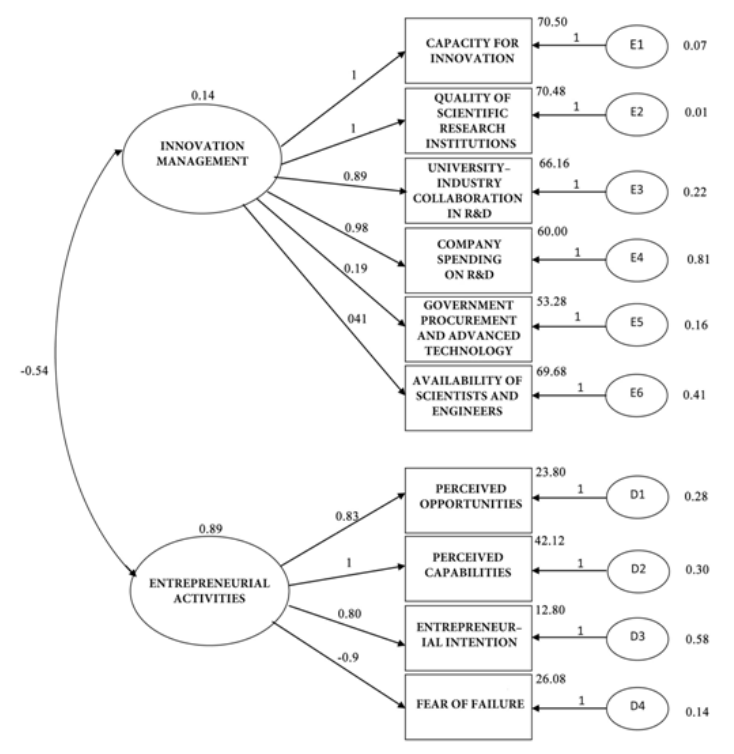

Fig. 5. structural equation modeling for The main variables in 2011 
For evaluating the fitness of the model variables and the final model, we can use many indices like the ones shown in Table 1, Table 2, Table 3 and Table 4.

Table 2

Fitness indices of the model for 2008

\begin{tabular}{lcc}
\hline & $N F I^{2}$ & $R M S E A^{1}$ \\
\hline Acceptance criteria & Is close to 1 & Is close to zero \\
\hline $\begin{array}{l}\text { statistical indices of the model for entrepreneurial activities and } \\
\text { perceptions }\end{array}$ & 0.71 & 0.21 \\
\hline Results & $\checkmark$ & $\checkmark$ \\
\hline
\end{tabular}

Table 3

Fitness indices of the model for 2009

\begin{tabular}{lll}
\hline & NFI & RMSEA \\
\hline Acceptance criteria & Is close to 1 & Is close to zero \\
$\begin{array}{l}\text { Statistical indices of the model for entrepreneurial activities and } \\
\text { perceptions }\end{array}$ & & 0.67 \\
Results & $\checkmark$ & $\checkmark$ \\
\hline
\end{tabular}

Table 4

Fitness indices of the model for 2010

\begin{tabular}{lll}
\hline Fitness indices & NFI & RMSEA \\
\hline Acceptance criteria & Is close to 1 & Is close to zero \\
Statistical indices of the model for entrepreneurial activities and & 0.63 & 0.28 \\
perceptions & & $\checkmark$ \\
Results & $\checkmark$ & $\checkmark$ \\
\hline
\end{tabular}

Table 5

Fitness indices of the model for 2011

\begin{tabular}{lll}
\hline & NFI & RMSEA \\
\hline Acceptance criteria & Is close to 1 & Is close to zero \\
$\begin{array}{l}\text { Statistical indices of the model for entrepreneurial activities and } \\
\text { perceptions }\end{array}$ & 0.7 & 0.29 \\
Results & $\checkmark$ & $\checkmark$ \\
\hline
\end{tabular}

Therefore, in the above model, first the relationship between these two variables was investigated. Then, the relation between each of the latent variables (activities and innovation) with their observed variables was studied. Finally, the correlation between the two sets of latent variables was investigated. The important point in the above model is the existence of a negative relationship between government's technological products and innovation. Of course, it is worth noting that fear of failure is one of the serious obstacles for entrepreneurial development and active people's attraction to entrepreneurship. Fear of failure involves fear of losing employment and financial account, others' diatribe, and relatives', colleagues', and rivals' humiliation and domination due to failure. In fact, in a society, adults do not take any actions to practice their business ideas because of their fear of failure. Despite the limited area of the research, the obtained result demonstrates this 
negative relationship. Having the final model and assuming the equality of variance, we can have the estimations and test the hypotheses for each element of the model.

Based on the results of Table 1 to Table 5, we can conclude that two determinants are not acceptable but we cannot reject the model. Based on the given determinants and comparing them with the ideal amount of the deserved model, it can be implied that there is an appropriate fitness and conformity for the research model. The remarkable point about fitness of the model is that if the fitness of the structural model does not verify that model, it never proves this unique model as an authentic one. Based on the performed experiments, since the outcome conformity is almost -1 , it can be proclaimed that there is a significant conformity between these two determinants (variables) only in the reversed form within these four years. In spite of this, since the conformities are very close to 1 in many cases, it is likely that there is a complete and positive relationship not only in the $0.05 \%$ error level but also in $0.1 \%$. Regarding the suppositions herein and also the performed structural equations model, the efficiency of innovation management in entrepreneurial comprehensions were -.91, -0.54, -0.93 and 0.54 from year 2008 to year 2011, respectively. As a result, the effect of innovation management on entrepreneurial comprehensions is reversed but very much in studied countries. Opposed with the public thoughts, it can be claimed that the more increase in innovation management, the more opposite outcome on entrepreneurial concepts in the countries under this research. Table 6 summarizes the finding of our survey.

Table 6

The summary of research findings

\begin{tabular}{lllll}
\hline index & 2008 & 2009 & 2010 & 2011 \\
\hline Capacity for innovation & $1+0.5$ & $1+0.47$ & $1+0.11$ & $1+0.07$ \\
Quality of scientific research institutions & $0.78+0.31$ & $0.89+0.9$ & $0.74+0.41$ & $1+0.01$ \\
University-industry collaboration in R\&D & $0.85+0.35$ & $0.90+0.11$ & $0.71+0.39$ & $0.89+0.22$ \\
Company spending on R\&D & $1.14-0.15$ & $1.04+0.4$ & $1.08+0.26$ & $0.98+0.81$ \\
$\begin{array}{l}\text { Government procurement and advanced } \\
\text { technology products }\end{array}$ & $0.47+0.29$ & $0.44+0.21$ & $0.37+0.18$ & $0.19+0.16$ \\
Availability of scientists and engineers & & & & \\
Perceived opportunities & $0.36+0.21$ & $0.32+0.5$ & $0.34+0.36$ & $0.31+0.41$ \\
Perceived capabilities & $1+0.54$ & $1+0.49$ & $1+0.46$ & $1+0.20$ \\
Entrepreneurial intention & $0.23+0.15$ & $0.93+0.58$ & $0.83+0.14$ & $0.83+0.28$ \\
Fear of failure & $0.76+0.33$ & $0.59+0.39$ & $0.8+0.23$ & $0.8+0.58$ \\
\hline & $0.27-0.79$ & $0.38-0.46$ & $0.19-0.39$ & $0.9-0.14$ \\
\hline
\end{tabular}

Table 7

The summary of the results of all four research hypotheses

\begin{tabular}{llc}
\hline Hypotheses & Description of the hypotheses & Results \\
\hline 1 & $\begin{array}{l}\text { There is a relationship between the latent variable of } \\
\text { Management and its observed variables }\end{array}$ & $\checkmark$ \\
2 & $\begin{array}{l}\text { There is a relationship between the latent variable of innovation } \\
\text { Management and observed variables of Entrepreneurial activities }\end{array}$ & $\checkmark$ \\
3 & $\begin{array}{l}\text { There is a relationship between the latent variable of Entrepreneurial } \\
\text { activities and its observed variables }\end{array}$ & $\checkmark$ \\
4 & Entrepreneurial activities have an effect on innovation Management & $\checkmark$ \\
\hline
\end{tabular}

\section{Conclusion}

Generally, there is a little evidence about the importance of innovation management for entrepreneurial activities throughout the world. In addition, Van's (2005) demonstrated the importance of fear of failure rate in starting a business in a region. The improvement of 
entrepreneurship has a considerable effect on the development of societies. In this regard, one of the basic aims of GEM has been to investigate the relationship between entrepreneurial activities and perceptions among the member countries of this consortium. However, the development of entrepreneurship requires constant investigation of entrepreneurial activities and perceptions in the country. The results of the structural equation modeling for testing the research hypotheses showed that for the relationship among the variables of entrepreneurial activities and innovation management, the standardized coefficient were $-.91,-0.54,-0.93$ and -0.54 from 2008 to 2011, respectively. As a result, one can infer that, among the studied countries, innovation management has a significant effect on entrepreneurial activities. Based on the findings of the study there is a significant influence of perceptions on activities and innovation correlation coefficient. Therefore, we understand that there is a significant relationship between these two variables with respect to innovation management, the Capacity for innovation, Quality of scientific research institutions, Company spending on R\&D, University-industry collaboration in $\mathrm{R} \& \mathrm{D}$, government procurement and advanced technology products, Availability of scientists and engineers. It is also suggested that innovation management teams are detected and prioritized in each of the provinces and the necessary information are provided through an Internet-based information bank of entrepreneurial opportunities. Furthermore, it is suggested that the effect of entrepreneurial perceptions on activities is studied in each region of the country. Finally, we can help the improvement of entrepreneurship level by designing the strategic development of entrepreneurship document in Iran.

\section{References}

Acs, Z.J., Audretsch, D.B., Braunerhjelm, P., \& Carlsson, B. (2005). The Knowledge Spillover Theory of Entrepreneurship,' Discussion Papers on Entrepreneurship, Growth and Public Policy, Group Entrepreneurship, Growth and Public Policy, Jena, Germany: Max Planck Institute of Economics.

Arundel, A., \& Hollanders, H. (2005). Policy, Indicators and Targets: Measuring the Impacts of Innovation Policies, European Trend Chart on Innovation, Enterprises Directorate-General, Brussels: European Commission, December.

Audretsch, D. B., \& Thurik, R. (2001). Linking Entrepreneurship to Growth. STI Working Papers, DSTI/DOC(2001)2, Paris: OECD, May.

Hoffman, A. (2005). Innovation Monitor 2005: Denmark's Innovation Capacity - from benchmarking to policy priorities. FORA, Division for Research and Analysis, Copenhagen: Ministry of Business and Economic Affairs, September.

Big, L, Fathian, M, \& Ghavamifar, A. (2005). The role of tacit knowledge in the management of creativity and innovation. The Third International Conference on Management, 29-42.

Boutellier, R., Gassmann, O., \& von Zedtwitz, M. (2000). Managing Global Innovation. Berlin: Springer. 30. ISBN 3-540-66832-2.

Caetano, M., \& Amaral, D.C. (2011). Road mapping for technology push and partnership: A contribution for open innovation environments, Technovation 31 (7), 320-335.

Casson, M. C., \& Wadeson, N. (2007). The discovery of opportunities: Extending the economic theory of the entrepreneur. Small Business Economics, 28, 285-300.

Casson, M. (1982). The Entrepreneur: An Economic Theory, Martin Robertson, Oxford.

Daft, R. (2007). Organization Theory and Design. South-Western College Pub, $10^{\text {th }}$ ed.

Dellabaraca, R. (2002). Understanding the opportunity recognition process in Entrepreneurship, and consideration of whether serial entrepreneurs undertake opportunity recognition better than novice entrepreneurs. MBA Dissertation, University Cambridge.

Drucker, P.F. (1985) Innovation and Entrepreneurship, London: Pan Books Ltd.

Hersham Morten, G., \& Hoffman, A. (2006). A General Policy Framework for Entrepreneurship. FORA, Division for Research and Analysis. Copenhagen: Ministry of Business and Economic Affairs, April. 
Global entrepreneurship Monitor (GEM) (2008-2011).

Hoffman, A. (2005). Innovation Monitor 2005: Denmark's Innovation Capacity - from

Huizingh, E.K.R.E. (2011). Open innovation: State of the art and future perspectives. Technovation, 31(1), 2-9.

Motohashi, K. (2011). Innovation and Entrepreneurship: A first look at linkage data of Japanese patent and enterprise census, RIETI Discussion Paper Series 11-E-007, 1-26.

Kruger, J., Schneider, J., \& Westermann, R. (2006). Clear view: An interactive context preserving hotspot visualization technique. Visualization and Computer graphics. IEEE Transactions on Visualization and Computer Graphics, 12(5), 941-948.

OECD (2001). Drivers of Growth: Information Technology, Innovation and Entrepreneurship, Science, Technology and Industry Outlook, Paris: OECD.

Shahhosseini, A \& Kavoosi, E. (2009). Innovation and Entrepreneurship, 1, Tehran: Aeeizh.

Srir Afraz, M. (2010). Commercialization of innovation, excellence strategy in the horizon of 1404 Iran. The first International Conference on Management, Innovation and Entrepreneurship. 22-30.

Trott, P. (2005). Innovation Management and New Product Development. Prentice Hall, ISBN 0273686437.

Venkataraman, S. (1997). The distinctive domain of entrepreneurship research: An editor's perspective. Advances in Entrepreneurship, 3, 119-138. 